\title{
1 Influence of hydraulic retention time and carbon loading rate on the
}

5

\section{production of algae}

C.M. Fernandez-Marchante, Y. Asensio, J. Lobato, J. Villaseñor, P. Cañizares, M.A. Rodrigo*

Department of Chemical Engineering. Faculty of Chemical Sciences \& Technologies. Universidad de Castilla La Mancha. Campus Universitario s/n 13071 Ciudad Real. Spain.

\section{Abstract}

This paper is focused on the assessment of the production of algae in batch bioreactors. Hydraulic retention time, carbon loading rate and light color were the inputs of the study and algae production the main output. Bioreactors were operated in semi-continuous mode and tests lasted two months, more than two times the period required to meet a steady-state response. This steady-state was verified with plateau responses in both, soluble parameters and suspended solids. Results points out the great relevance of temperature. Likewise, they show that green light improves the production of algae, as well as long HRT and high CLR. Maximum production rates attained were in the range 4-14 $\mathrm{mg} \mathrm{TSS} \mathrm{d}{ }^{-1} \mathrm{~L}^{-1}$. The ratio COD /TSS for this biofuel was almost constant $(3.13 \mathrm{mg}$ COD mg-1 TSS) but the quality of the product obtained in terms of the Mean Oxidation State of Carbon is completely different. Longer HRT leads to lower MOSC and hence to potentially more valuable fuels.

\section{Keywords}

Algae production; carbon fixation; light; hydraulic retention time; carbon loading rate

\section{Chlorella vulgaris}


- Algae production depends on light color, being green illumination the best choice

- $\quad$ The higher the HRT and CLR, the higher is the resulting algae production

- $\quad$ Ratio COD/TSS of the algae produced is ca. $3.13 \mathrm{mg} \mathrm{COD} \mathrm{mg}^{-1} \mathrm{TSS}$

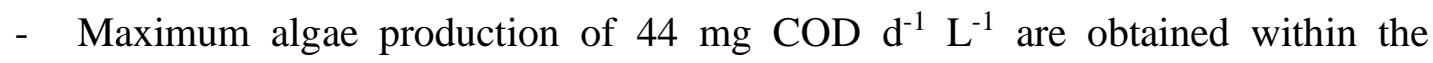
conditions studied

33

- Quality of product as fuel (as MOSC) improves with longer HRT and for CLR around $10 \mathrm{mg} \mathrm{C} \mathrm{d}^{-1} \mathrm{~L}^{-1}$

35

*author to whom all correspondence should be addressed: manuel.rodrigo@uclm.es

39

40 


\section{Introduction}

Production of microalgae is one of the most promising ways to simultaneously transform inorganic carbon into organic carbon and to harvest energy from sun (Farooq et al., 2015).

This type of microorganisms can be easily processed in aqueous suspensions and this easiness in the processing, as compared to plants, makes them good candidates for developing industrial processes in which photosynthetic beings are used to take advantage of the sun energy. Consequently, their application in energy transformation devices have been a topic worthy of research for decades, in the search for sources of energy and/or technologies that minimize the production of carbon dioxide (Chen et al., 2015). Today, these applications are investigated even with a higher interest, because of the day-to-day clearer effects of the climate change on Earth, which are reflected on a higher average temperature associated to the greenhouse effect.

Photosynthesis is the key to understand the performance of a microalgae culture. In fact, it is the primary energy source for the anabolic processes, which transform inorganic carbon into new microalgae components. As in any other biological process, these anabolic processes requires not only of a carbon source but also of nutrients and suitable operation conditions. At this point, unlike microorganisms in wastewater treatment processes (f.i. activated sludge) or in energy production (f.i. methanogens), from the viewpoint of chemical engineers, algae are less well-known organisms and only conditions related to their industrial production have been widely studied in the search of an efficient process to fix inorganic carbon (Sostaric et al., 2009). Microalgae are known to exhibit high growth rates, high lipid production capacity, high $\mathrm{CO}_{2}$ fixation rates, and low land use, as compared to other energy crops (Amin, 2009; Zeng et al., 2011; Patzelt et al., 2015). An additional advantage is that they can succeed under conditions with high 
level of $\mathrm{CO}_{2}$. This characteristic makes microalgae suitable even for using $\mathrm{CO}_{2}$ contained in waste flue gases emitted from industrial facilities or power plants for its growth. Applications of microalgae are not limited to production of biofuels, but they are also used in environmental remediation processes (Park et al., 2011; Ruiz et al., 2013). Thus, microalgae are capable of blooming in poor-quality water, such as municipal, industrial or agricultural wastewater and they can efficiently recover nutrients such as nitrogen $(\mathrm{N})$ and phosphorus $(\mathrm{P})$ from wastewater streams, improving wastewater quality (Aslan and Kapdan, 2006; Martinez et al., 1999; Xin et al., 2010; Ruiz-Marin et al., 2010; Caporgno et al., 2015). Likewise, they have a well-known role in the widely applied lagooning treatment technology. As it is well-known, lagooning is a wastewater treatment technology widely-recommended as a soft treatment because of its easiness of operation. In those systems, synergistic coexistence of algae and heterotrophic microorganisms attains treatment of wastewater with a very efficient technology in terms of energy consumption, because oxygen required for aerobic microorganisms is provided not by mechanical aerators or blowers. Opposite, it is directly produced by algae during photosynthesis. The main drawback is the necessity of large treatment areas. This drawback is typically associated with the stationarity of algae (with daily cycles associated to sunlight) and low growing rate of algae in natural systems (Ahmad et al., 2013).

The production of fuels from bicarbonates or carbon dioxide using algae and sunlight can contribute to minimize the use of fossil fuels with the production of alternate biofuels. Literature shows that microalgal biomass can be used to produce a broad portfolio of fuels, such as biodiesel, bioethanol, and biogas (Jacob-Lopes et al., 2008; Jacob-Lopes et al., 2009; Rusten and Sahu, 2011; Yeh et al., 2010). However, carling up cultivation systems is still a challenge due to difficulty in controlling the optimum conditions for 
microalgae growth (Guieysse et al., 2013). In fact, it is reported (Ahmad et al., 2013) that the development of microalgal biofuels is currently limited by the high production cost, as compared with both first and second generation biofuels, and that the energy required for cultivating algae exceeded the energy content of the algae produced (Murphy and Allen, 2011). This controversy has limited the full-scale applicability and push up the research in different topics, even in their separation process once produced (Souza et al., 2016).

At this point, in looking for applications at small-scale (f.i. to provide a small fuel cell or microbial fuel cell for portable devices (Asensio et al., 2018; Fernández- Marchante et al., 2018), there is very few information about production rates and influence of the different inputs on the performance of the biofuel production process. With this background, the goal of this paper is to learn how light color (with the applications of LEDs (Park et al., 2012; Schulze et al., 2014)), hydraulic retention time (HRT) and carbon loading rate (CLR) can influence on the performance of an algae culture, in order to determine the best parameters for their growth and later use. Chlorella vulgaris was selected as the model microalgae due to its rapid growth, good properties as a fuel, efficient organic and nutrient uptake characteristics from wastewater, and predominance in most wastewaters worldwide, including temperate climates (Ge et al., 2018; Asensio et al., 2018). Chlorella vulgaris whose order is Chlorococcales, belongs to the family of Oocytaceae and its genus is Chlorella.

This research aimed to apply this knowledge to produce fuel from carbon dioxide for microbial fuel cells, within a much wider research portfolio carried out in our lab (Asensio et al., 2018; Souza et al., 2016; Gonzalez del Campo et al., 2013; Lobato et al., 2013; Fernández-Marchante et al., 2018). For this reason, conditions applied are far from those used in other studies shown in the literature. Experiments were carried out in batch 
117 bioreactors for which illumination, temperature, hydraulic residence time (HRT) and carbon loading rate (CLR) were controlled.

\section{Materials and methods}

\subsection{Microalga strain and culture medium}

Chlorella vulgaris, purchased from the Spanish bank of algae (Spain) was used as initial seed, and $25 \mathrm{~L}$ tank was used to produce the initial suspension. It was prepared in phototrophic and non-axenic condition, in Bold's Basal freshwater nutrient solution using $\mathrm{CO}_{2}$ like carbon source and natural light. The tank was open to the atmosphere and $\mathrm{CO}_{2}$ was bubbled every 3 days for 15 minutes with a flow rate of $1.6 \mathrm{~L} \mathrm{~min}^{-1}$.

\subsection{Acclimatisation in new culture medium}

Table 1. Compositions of Bold's Modified Basal mediums

\begin{tabular}{ccc}
\hline Compound & First medium (g/L) & Second medium(g/L) \\
\hline $\mathrm{NaHCO}_{3}$ & 0.220 & 1.100 \\
$\mathrm{MgSO}_{4} \cdot 7 \mathrm{H}_{2} \mathrm{O}$ & 0.075 & 0.375 \\
$\mathrm{~K}_{2} \mathrm{HPO}_{4}$ & 0.175 & 0.875
\end{tabular}




\begin{tabular}{ccc}
$\mathrm{NaNO}_{3}$ & 0.125 & 0.625 \\
$\mathrm{NH}_{4} \mathrm{Cl}$ & 0.125 & 0.625 \\
$\mathrm{KH}_{2} \mathrm{PO}_{4}$ & 0.075 & 0.375 \\
$\mathrm{CaCl}_{2} \cdot 2 \mathrm{H}_{2} \mathrm{O}$ & 0.025 & 0.125 \\
$\mathrm{EDTA}$ & 0.050 & 0.250 \\
$\mathrm{NaCl}$ & 0.025 & 0.125 \\
$\mathrm{KOH}$ & 0.031 & 0.155 \\
$\mathrm{H}_{3} \mathrm{BO}_{3}$ & 0.011 & 0.057 \\
$\mathrm{FeSO}_{4} \cdot 7 \mathrm{H}_{2} \mathrm{O}$ & 0.005 & 0.025 \\
$\mathrm{H}_{2} \mathrm{SO}_{4}(\mu \mathrm{L})$ & 1.0 & 5.0 \\
$\mathrm{ZnSO}_{4} \cdot 7 \mathrm{H}_{2} \mathrm{O}$ & 0.008 & 0.041 \\
$\mathrm{MnCl}_{2} \cdot 4 \mathrm{H}_{2} \mathrm{O}$ & 0.002 & 0.009 \\
$\mathrm{CuSO}_{4} \cdot 5 \mathrm{H}_{2} \mathrm{O}$ & 0.002 & 0.008 \\
\hline
\end{tabular}

146

147

148

149

150

151

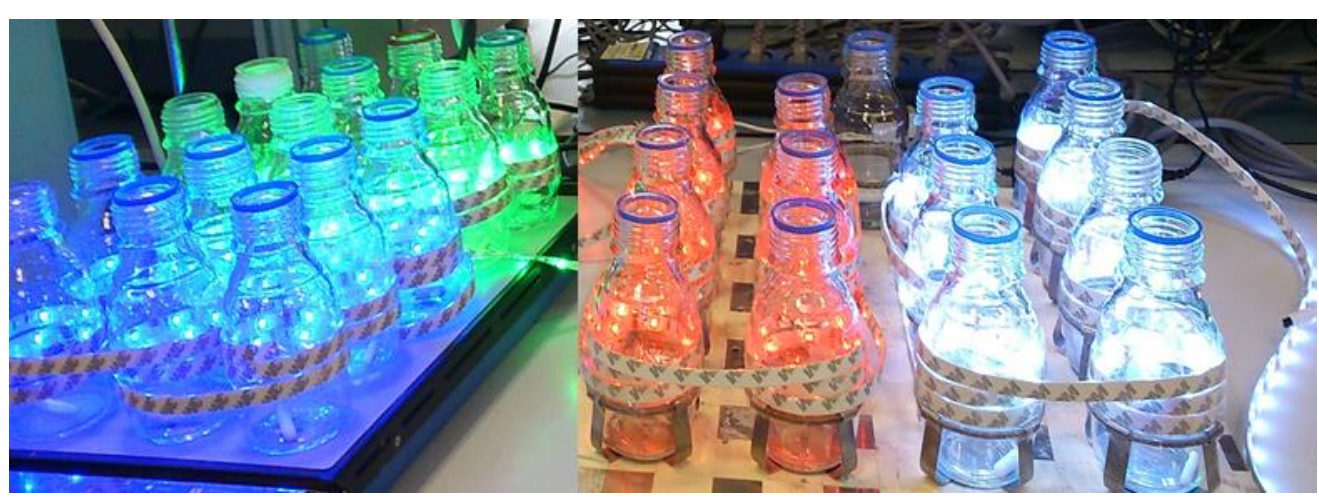

152

153

154

155

Table 2. Acclimatisation and growth of algae using $\mathrm{NaHCO}_{3}$ like carbon source

\begin{tabular}{ccccccc}
\hline \multicolumn{6}{c}{ Acclimatisation (1 cycle of 1 day, first medium and 19-19,3 $\left.{ }^{\circ} \mathbf{C}\right)$} \\
\hline Test & $\begin{array}{c}\mathbf{V}_{\text {inoculum }} \\
(\mathbf{L})\end{array}$ & $\begin{array}{c}\mathbf{V}_{\text {sample }} \\
(\mathbf{L})\end{array}$ & $\begin{array}{c}\mathbf{V}_{\text {food }} \\
(\mathbf{L})\end{array}$ & $\begin{array}{c}\mathbf{V}_{\text {water }} \\
(\mathbf{L})\end{array}$ & $\begin{array}{c}\text { HRT } \\
(\mathbf{d})\end{array}$ & $\begin{array}{c}\text { CLR } \\
(\mathbf{m g} \mathbf{C} / \mathbf{d} \\
\mathbf{L})\end{array}$ \\
\hline 1 & 0.190 & 0.010 & 0.01 & 0.00 & 20.0 & 5.5 \\
2 & 0.175 & 0.025 & 0.01 & 0.015 & 8.0 & 5.5 \\
3 & 0.150 & 0.050 & 0.01 & 0.040 & 4.0 & 5.5 \\
4 & 0.125 & 0.075 & 0.01 & 0.065 & 2.7 & 5.5 \\
5 & 0.150 & 0.050 & 0.02 & 0.030 & 4.0 & 11.0 \\
6 & 0.150 & 0.050 & 0.03 & 0.020 & 4.0 & 16.5 \\
7 & 0.150 & 0.050 & 0.05 & 0.000 & 4.0 & 27.5 \\
\hline
\end{tabular}

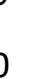

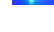

Figure 1. Set of 28 illuminated reactors with four different LEDs (red, green, blue and white) (before covering the reactors with aluminium) 


\subsection{Operations of photobioreactors systems and culture conditions}

The acclimated reactors were used in two sets and carried out under different light illumination, hydraulic retention time (HRT, ranging from 8 to 60 days) and carbon loading rate (CLR, ranging from 18-100 $\mathrm{mg} \mathrm{C} \mathrm{L}^{-1} \mathrm{~d}^{-1}$ ) (See Table 3). The reactors were operating in semi-continuous mode (SBR) for 50 days. Sequential batch photobioreactors were standing at room temperature and for this reason this study started at $19^{\circ} \mathrm{C}$.

Table 3. Operations of photobioreactors systems and culture conditions

\begin{tabular}{|c|c|c|c|}
\hline \multicolumn{2}{|c|}{$\begin{array}{c}1^{\text {st }} \text { set } \\
(20 \text { cycles of } 2 \text { days }) \\
\text { First medium } \\
\end{array}$} & \multicolumn{2}{|c|}{$\begin{array}{c}2^{\text {nd }} \text { set } \\
\text { (3 cycles of } 3 \text { days) } \\
\text { Second medium }\end{array}$} \\
\hline $\begin{array}{c}\text { HRT } \\
\text { (d) }\end{array}$ & $\begin{array}{c}\text { CLR } \\
(\mathbf{m g ~ C / d} \\
\mathbf{L})\end{array}$ & $\begin{array}{r}\text { HRT } \\
\text { (d) }\end{array}$ & $\begin{array}{c}\text { CLR } \\
(\mathbf{m g ~ C / d} \\
\mathbf{L})\end{array}$ \\
\hline 40.0 & 5.5 & 60 & 18.3 \\
\hline 16.0 & 5.5 & 24 & 18.3 \\
\hline 8.0 & 5.5 & 12 & 18.3 \\
\hline 5.4 & 5.5 & 8 & 18.3 \\
\hline 8.0 & 11.0 & 12 & 36.7 \\
\hline 8.0 & 16.5 & 12 & 55.0 \\
\hline 8.0 & 27.5 & 12 & 91.7 \\
\hline
\end{tabular}

\subsection{Analytical methods}

Conductivity, $\mathrm{pH}$, and dissolved oxygen were measured using a GLP 31 Crison ${ }^{\circledR}$ conductivity-meter, a GLP22 Crison ${ }^{\circledR}$ pH-meter and a Oxi538 WTW® oxy-meter, respectively. Chemical oxygen demand (COD) was determined using a Velp ECO-16 digester and a Pharo 100 Merck spectrophotometer analyzer. Cell mass was measured by optical density (OD) measurements on a Shimadzu UV-1700 spectrophotometer analyzer at $550 \mathrm{~nm}$, where Chlorella vulgaris has the maximum absorption peak. Solid suspended solids (TSS) were measured gravimetrically according to standard methods. The samples were filtered through glass microfiber discs and the dry weight of pellets was weighed after drying at $105^{\circ} \mathrm{C}$ for four hours (until weight value was stabilized). Chlorophyll was measured by spectrophotometric method with an extracting agent (methanol). $10 \mathrm{~mL}$ of Chlorella vulgaris samples were centrifuged during ten minutes at $13000 \mathrm{rpm}$. The 
supernatant was removed and the pellets were suspended in a known volume of methanol until $10 \mathrm{~mL}$. Chlorophyll extraction is favored heating the pellets with methanol at $50{ }^{\circ} \mathrm{C}$ during one hour, after that the samples were centrifuged during ten minutes at the same rpm. For the spectrophotometric analysis of the samples, the supernatant was measured at two different wavelengths, $665 \mathrm{~nm}$ and $750 \mathrm{~nm}\left(\mathrm{~A}_{665}\right.$ and $\left.\mathrm{A}_{750}\right)$. The spectrophotometer was blanked with methanol. Finally, chlorophyll concentration was calculated following this expression.

Chlorophyll $=13.9 *\left(\mathrm{~A}_{665}-\mathrm{A}_{750}\right) * \mathrm{~V}_{\mathrm{MeOH}} / \mathrm{V}_{\mathrm{s}} * \mathrm{w}$

Where, $\mathrm{Vs}(\mathrm{mL})$ is the sample volume, $\mathrm{V}_{\mathrm{MeOH}}(\mathrm{mL})$ is the methanol volume, $\mathrm{A}_{665}$ is the absorption at $665 \mathrm{~nm}, \mathrm{~A}_{750}$ is the absorption at 750 and $\mathrm{w}$ is the cell width (cm) (Sostaric et al., 2009)

\section{Results and Discussion}

\subsection{Study of the stability of the biological culture}

Figures 2 and 3 show the time course of the different parameters monitored during a test in which algae production is evaluated from the initial stage of seeding till the steady state is reached for each parameter (HRT 16 days and CLR $5.5 \mathrm{mg} \mathrm{C} \mathrm{d}^{-1} \mathrm{~L}^{-1}$ ). The seeding was made with a strongly concentrated dispersion of Chlorella vulgaris obtained by concentrating algae by sedimentation. These algae were produced from more than one year in a large bioreactor in order to have algae enough to use the same seeding in each of tests carried out.

As it can be observed, steady state conditions are reached after 30 days of operation (plateau of the parameter vs time plot). It is worth to remind that the reactor operates in semi-continuous mode, because it is not fed continuously but only once every two days and because of the expected influence of the light/dark daily cycles applied on its 
performance. Time constants for dynamic responses are much higher than a day, as it can

202

203

204

205

206

207

208

209

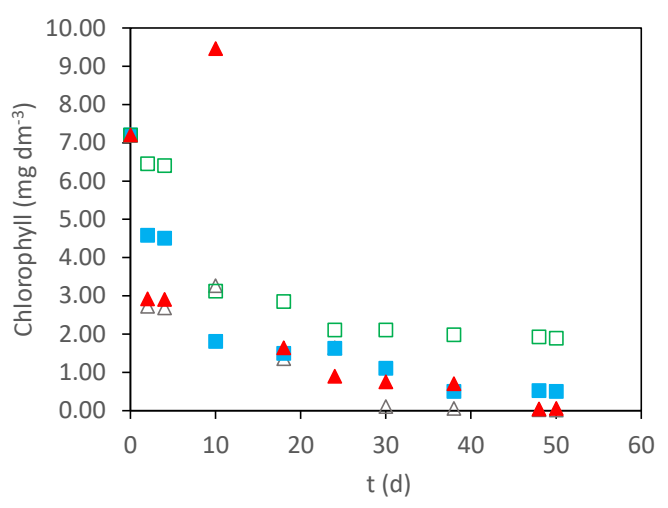
best fit to results over long periods. be easily concluded from the figure (63.2\% of the response is obtained after c.a. 10 days). This fact helps to explain the necessity of long experimental periods. Shortest hydraulic retention time applied in this series of tests is over five days. HRT of the test shown in the figures is sixteen days. In addition, because of that operation mode and of the high time-constants, results of long experiments should be discussed as if they were obtained in a continuous reactor, taking into account that this is the theoretical flow pattern that

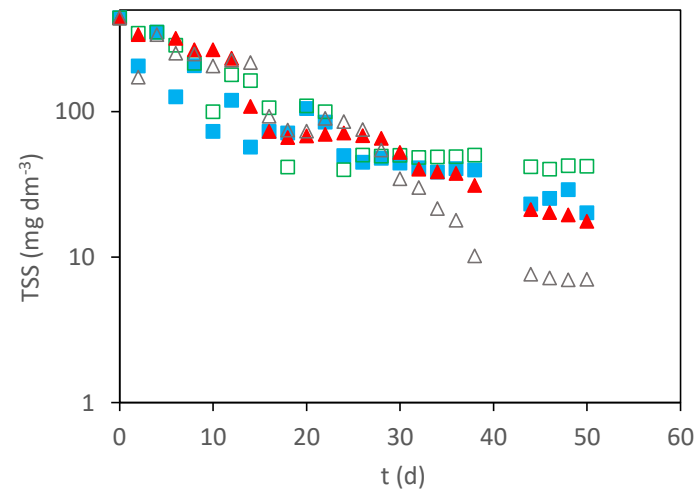

210

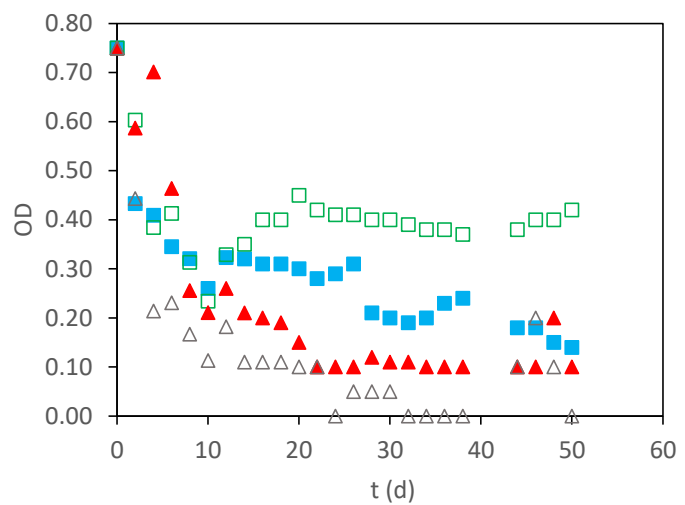

211 Figure 2. Time-course changes in the algae concentration during the operation of algae producing bioreactors illuminated with $\square$ blue, $\square$ green, $\boldsymbol{\Delta}$ red and $\Delta$ white light. Bioreactors were operated at $19.3^{\circ} \mathrm{C}, 16$ days (HRT) and $5.5 \mathrm{mg} \mathrm{C} \mathrm{d}^{-1} \mathrm{~L}^{-1}$ (CLR) 
215 Regarding Figure 2, algae can be quantified with different parameters and each of them 216 has a different meaning. The most interesting are the optical density, the chlorophyll 217 concentration and the total suspended solids. Within them, the chlorophyll and the optical density can be directly related to the activity of living algae, while the total suspended solids measurement informs about both, the living and dead algae. So, TSS is also interesting when the use of algae as potential substrate is being looked for, but not in order to know how to produce more organic substrate from the nutrient solution in the bioreactor. In comparing chlorophyll and optical density, the first is more accurate, taking into account the higher selectivity associated to the extraction procedure used in the quantification of chlorophyll. In fact, optical density quantifies all green-colored substances in the mixed liquor.

In comparing results, due to the large concentration used to seed the bioreactors and the low CLR applied for feeding $\left(5.5 \mathrm{mg} \mathrm{C} \mathrm{d}^{-1} \mathrm{~L}^{-1}\right)$, the concentration of the three parameters decreases over the tests down to the steady state values, for which influence of light is clearly observed in the four tests, being more efficient the green light, followed by blue, red and white lights. These results are more clearly seem in optical density and chlorophyll, which are the parameters more strongly related to living algae, but they also reflects on the value of the TSS. Initially, this observation may suggest that green light favors the production of algae in the reactors (Gutierrez-Wing et al., 2014), although this observation will be further discussed afterwards in this manuscript, during the comparison with other conditions.

Figure 3 focuses on two relevant parameters in every biological processes: the conductivity and the $\mathrm{pH}$. Both parameters were not controlled but only monitored over the tests and, as shown in the Figure, they also reach a steady-state value. Opposite to the parameters that quantified algae, these parameters stands for soluble species. It is 
important to point out the comparison of particulate and soluble parameters, whose dynamic behavior seems to be very comparable. This observation can be explained because the hydraulic and solids retention time were kept within the same values, as the volume of mixed liquor taken periodically from the reactor and replaced with fresh feeding solution was completely-mixed (and hence with a homogeneous concentration).
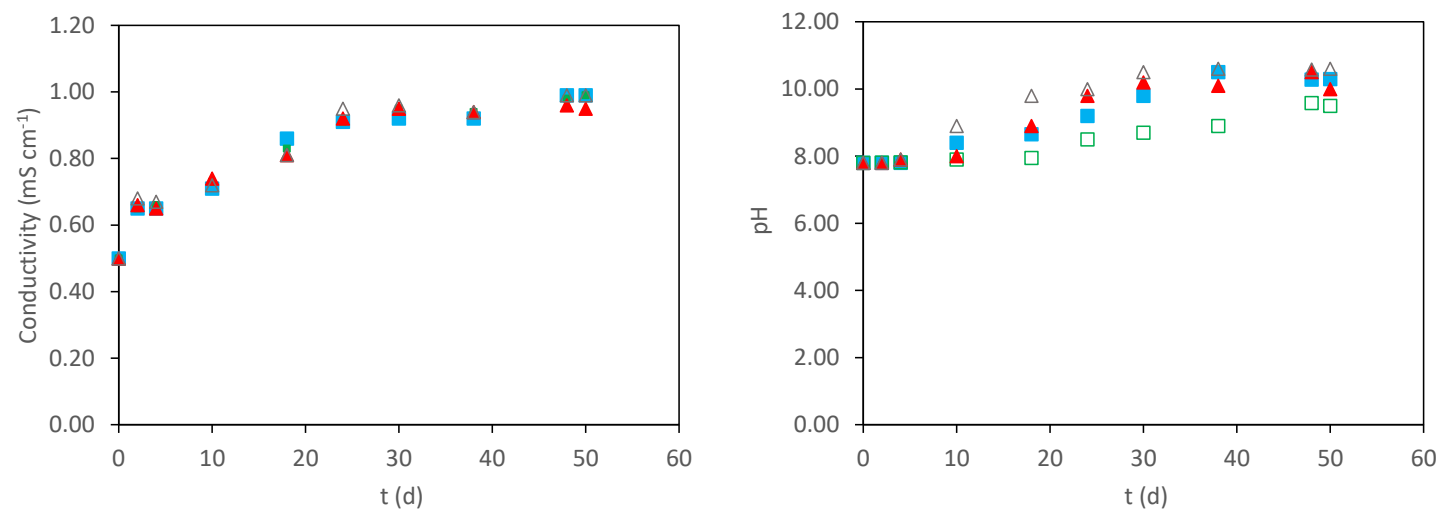

Figure 3. Time-course changes in the conductivity (part a) and $\mathrm{pH}$ (parte b) during the operation of algae producing bioreactors illuminated with $\square$ blue, $\square$ green, $\boldsymbol{\Delta}$ red and $\triangle$ white light. Bioreactors were operated at $19.3{ }^{\circ} \mathrm{C}(\mathrm{T}), 16$ days (HRT) and $5.5 \mathrm{mg} \mathrm{C} \mathrm{d}^{-1}$ $\mathrm{L}^{-1}(\mathrm{CLR})$

Regarding the values reached, conductivity increases more than $40 \%$ over the experiment and no influence of light was observed. This increase can be explained by the high salinity of the nutrient solution used to feed the bioreactors (conductivity of that solution was 1.65 $\mathrm{mS} \mathrm{cm}^{-1}$ ). Meanwhile, the $\mathrm{pH}$ becomes more basic during the tests and it stabilizes within the range 9-10. The lowest value was obtained in the bioreactor illuminated with the green light. In comparing the steady-state algae concentration and $\mathrm{pH}$, initially, data seems to indicate that the lower the $\mathrm{pH}$, the better is the performance of the reactor in terms of algae production (higher steady state concentration). Indeed, it has been seen that initially 
the salinity of the reactor harms and inhibits the long-term development. The culture medium must consist of fresh water, although they can tolerate a wide range of salt concentrations since they possess osmoregulation mechanisms. However, salt concentrations can produce inhibition of photosynthesis and growth, and an excessive salt content can cause plasmolysis. A disadvantage of using bicarbonate as a carbon source is that its concentration increases the $\mathrm{pH}$, with the optimum $\mathrm{pH}$ being between 7 and 9 . Outside of this range its growth may also be inhibited.

Dynamic data obtained over the tests always evolves in the same fashion, being stabilized within steady-state values after 15 days, for the worst case. Hence, it is important to compare the effect of the two most relevant inputs (carbon loading rate and hydraulic retention time) on the steady-state performance of the system in order not to get lose with the huge amount of dynamic data obtained over the tests.

\subsection{Influence of operating conditions}

Figures 4 and 5 compares the steady - state $\mathrm{pH}$ and conductivity reached after 54 days of operation for the different tests, for which the HRT (Figure 4) or the CLR (Figure 5) are modified keeping the other parameter constant. It is important to point out that $\mathrm{pH}$ changed over the day because of the day/night cycles and that data shown in the figure correspond to the samples taken every day at 10:00 a.m. at the end of the cycle of operation (before replacing the target amount of mixed liquor with fresh feeding solution), always after 2.5 hours of light illumination. The same explanation applies for conductivity, because not only bicarbonates but other nutrients contained in the feeding 

correspond just to the same conditions.
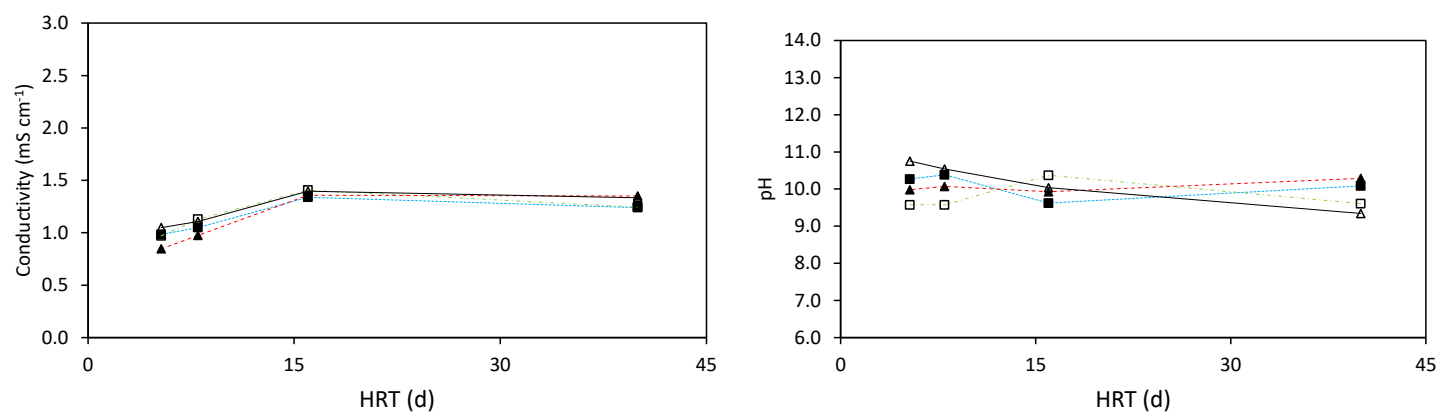

287

Figure 4. Influence on the steady-state $\mathrm{pH}$ and conductivity of the hydraulic retention time (HRT) in semi-continuous bioreactors illuminated with $\square$ blue, $\square$ green, $\boldsymbol{\Delta}$ red and
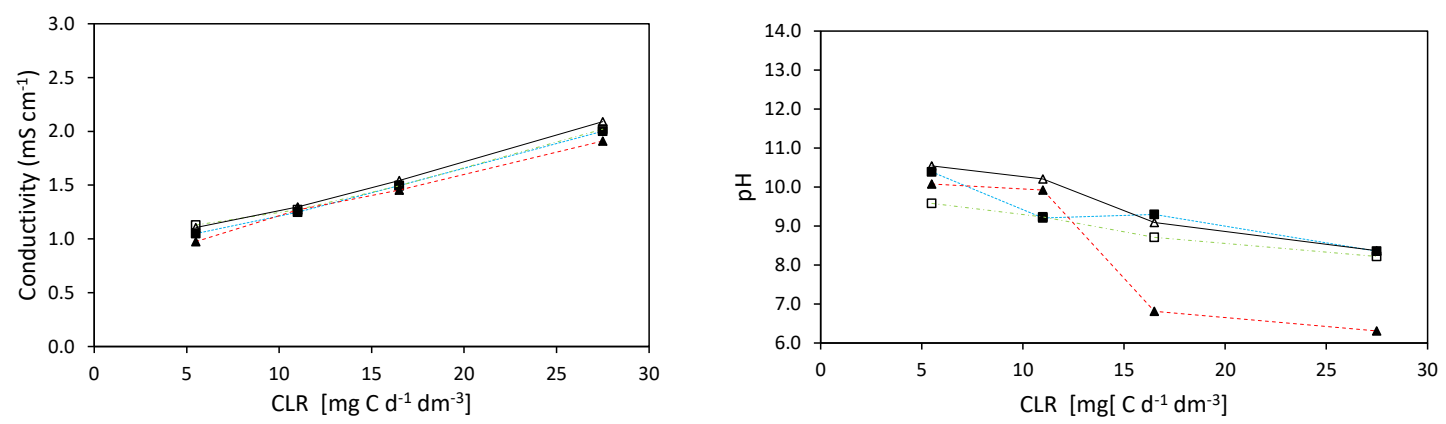

Figure 5. Influence on the steady-state $\mathrm{pH}$ and conductivity of the nutrient load fed to semi-continuous bioreactors illuminated with $\square$ blue, $\square$ green, $\boldsymbol{\Delta}$ red and $\triangle$ white light. Operation conditions of $1^{\text {st }}$ set: T $19.3^{\circ} \mathrm{C}$; HRT 8 days

Regarding $\mathrm{pH}$, there is a decrease with the increase in both parameters (CLR and HRT) although changes are not extreme and this parameter is kept within reasonable values, at 
301

302

303

304

305

306

307

308

309

310

311

312

313

314

315

316

317

318

319

320

321

322

323

324

325

least from the view point of algae viability. Almost no influence of the light used on the value reached, except for a higher decrease observed in the test carried out with the red light and high nutrient loads.

During photosynthesis, algae consume carbon dioxide, raising the $\mathrm{pH}$ (photosynthesis overcomes respiration in the net balance between production and consumption of carbon dioxide), while over nights the $\mathrm{pH}$ decreases due to respiration. The primary role of the photosynthesis explains the alkaline pHs measured in the mixed liquor of the reactor. This is a particularly interesting value, because the $\mathrm{pH}$ of the nutrient solution is 6.40 and the initial $\mathrm{pH}$ of the mixed liquor in the tanks was around 8.2.

Conductivity informs about the concentration of ionic species in the reaction media and it is strongly related to the solution fed to bioreactors. This is clearly observed in Figure 5 , because of the linear increase of the conductivity with the CLR. The solution fed to the reactor consists of nutrients and bicarbonates as explained in the Materials \& Methods section. These components are used in anabolic reactions to synthetize the new algae. Hence the increasing concentration with the CLR should be explained in terms of the accumulation of ions not used in those reactions or formed from different anabolic and catabolic reactions after its processing by algae. Regarding the HRT, a very slight increase followed by stabilization is observed. In this case the amount of nutrients added were the same in each test. Hence, differences obtained at lower HRT (higher amount of water) are due to the dilution of the salt concentration added due to the methodology used to fix the HRT. In any case, the almost nil influence of the light illuminated is pointing out that conductivity is not greatly affected by the biological process carried out by algae.

Figure 6 shows the influence of HRT on the steady state concentration of algaequantifying parameters, in bioreactors operated at $19.3^{\circ} \mathrm{C}$. As explained before, due to the operating procedure in these experiments, the HRT and the solid retention time (SRT) 
are equal, because the reaction product is taken from a perfectly mixed suspension.

327 Taking into account the meaning of each parameter, it can be observed that parameters related to substrate production increases with the HRT, being more efficient the bioreactor irradiated with green light. The increase can be related to the accumulation of algae in the system because of the lower volume of product taken at higher HRT. Regarding chlorophyll, same behavior is observed in three of the bioreactors (irradiated with red, blue and white lights) and a completely different behavior is observed in the reactor irradiated with green light, with a higher accumulation of "living algae" at lower HRT.

This observation can be an indicative of the better performance of the system when it is irradiated with green light and the better conditions for algae survival (Mohsenpour and Willoughby, 2013; Terashima et al., 2009).
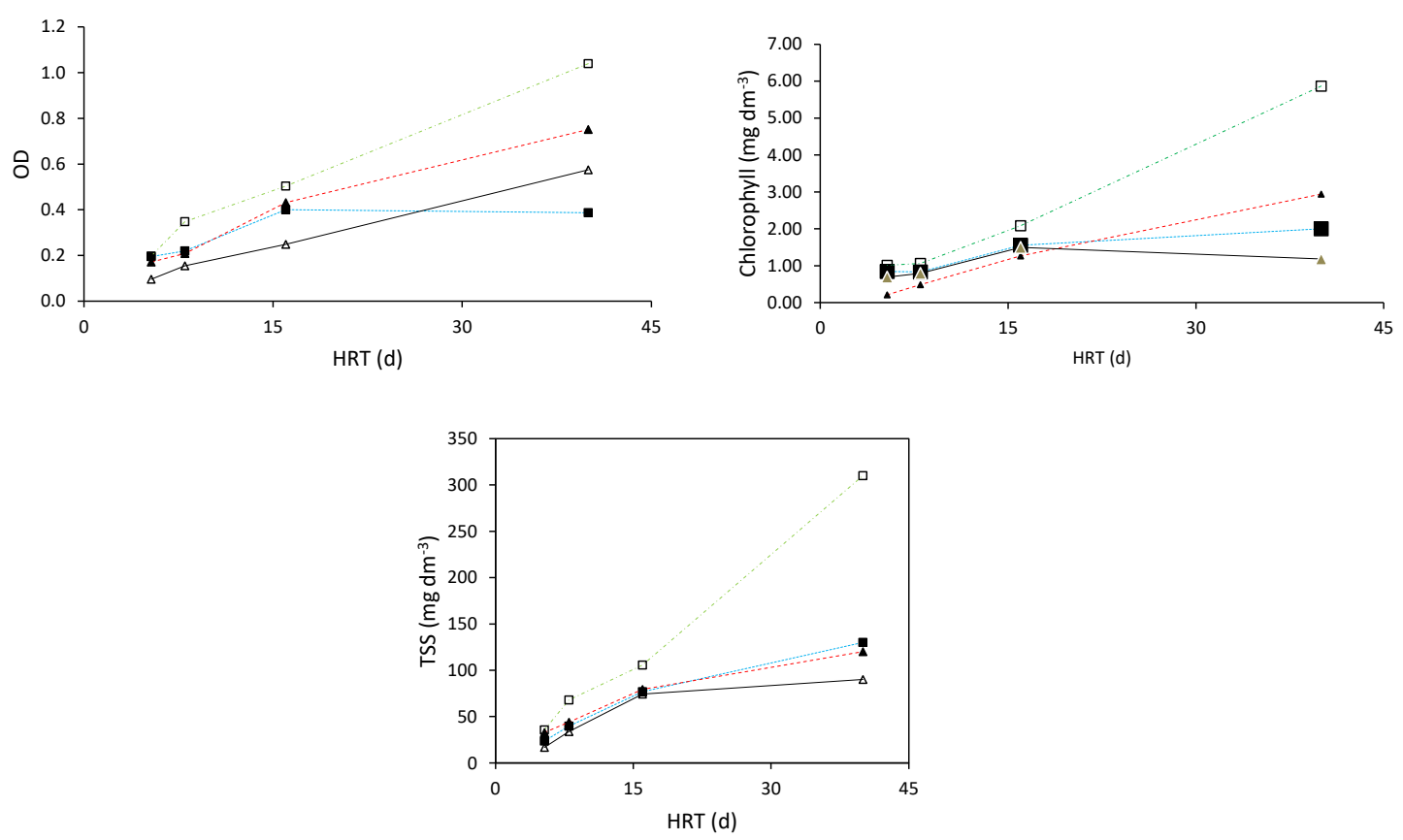

Figure 6. Influence on the steady-state algae concentration of the hydraulic retention time 
These results are confirmed in Figure 7, in which the production of algae in this reactor is shown. As it can be observed the increase in the concentration of algae obtained with the higher HRT has a positive effect on the production of algae, expressed both as total biomass production (TSS) and as living algae (chlorophyll). This is an expected outcome because algae growth depends directly on the concentration of algae. Green light has a very important influence on results and promotes the activity of living algae. Red, blue and while lights have less influence on the production of living algae this reflects in a lower production of biomass, which, opposite, is favored by HRT.
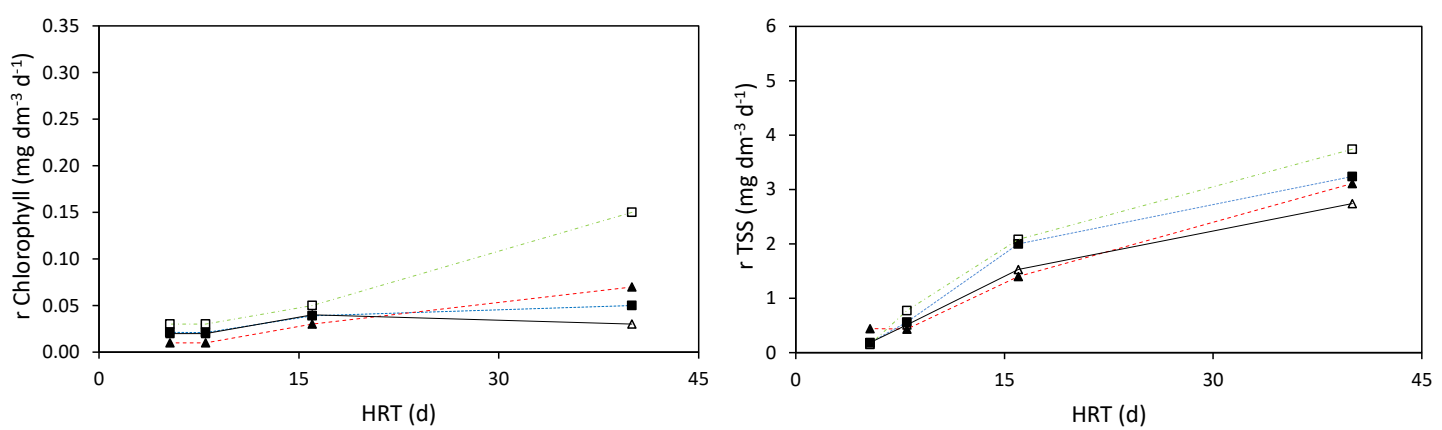

Figure 7. Influence of the HRT on the steady-state production of algae in semicontinuous bioreactors illuminated with Dblue, green, $\Delta$ red and $\Delta$ white light operated at mild temperatures $\left(19.3^{\circ} \mathrm{C}\right)$. CLR: $5.5 \mathrm{mg} \mathrm{C} \mathrm{d}^{-1} \mathrm{~L}^{-1}$

The other important parameter studied in this work is the CLR fed to the bioreactors. The production of algae is improved with the nutrient load applied and positive effect of the green light irradiation is very clearly seen. In fact, a Monod-type performance can be seem (clearly observed in the case of the green light) (Sasi et al., 2011; Filali et al., 2011; He et al., 2012). As it was stated before with the influence of the HRT, differences between productions of algae in reactors irradiated with other light are smaller. Regarding the production of biomass, differences are shorter, as they were in the case of the HRT, 
meaning that in considering both living and death algae there are less differences caused by light. Maximum production rates are about $4 \mathrm{mg} \mathrm{TSS} \mathrm{L}^{-1} \mathrm{~d}^{-1}$ (Figure 8) in stationary phase.
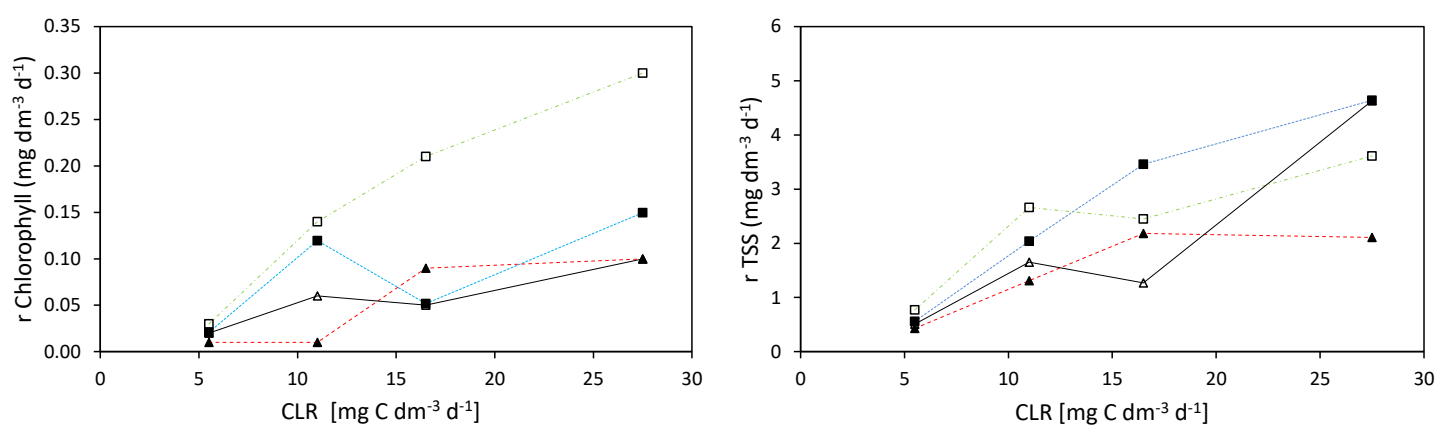

Figure 8. Influence on the steady-state solid algae production of the CLR in semicontinuous bioreactors illuminated with $\square$ blue, $\square$ green, $\boldsymbol{\Delta}$ red and $\triangle$ white light, operated at mild temperatures $\left(19.3^{\circ} \mathrm{C}\right)$. HRT 8 days.

As in any other biological process, temperature is a very important parameter. In order to evaluate the influence of this parameter some tests $\left(2^{\text {nd }}\right.$ set $)$ were carried out at $33^{\circ} \mathrm{C}$, fourteen ${ }^{\circ} \mathrm{C}$ above the other 1 st set. In those experiments, the ranges of HRT and CLR were enlarged, trying to obtain more information about performance at higher HRT and CLR.

Results obtained were unexpected. The production of algae (both in terms of chlorophyll and TSS) increases with the HRT in the range 10-60 days (as expected according to the tests carried out at $19^{\circ} \mathrm{C}$ ), indicating that long residence times in the reactor favor a proper production of algae (Figure 9). However, the maximum production rate was observed operating at the lowest HRT tested (close to $14 \mathrm{mg} \mathrm{TSS} \mathrm{d}^{-1} \mathrm{~L}^{-1}$ ) and this behavior was confirmed in the four sets of tests carried out with different light illuminated, indicating that there are at least two different controlling mechanisms in the production of algae. A 
possible explanation of this experimental observation can be related to the different growing stage of the algae culture. For lower HRT tests, an exponential-growth stage could be the primary growing phase, while for longer HRT the stationary phase becomes the primary phase and this supports the lower rates observed (Senez, 1962). Anyhow, values obtained at the highest HRT are similar at both temperatures. Hence, production of biomass for longer HRT is quite within the same range than in the case of lower temperature (around $4 \mathrm{mg} \mathrm{TSS} \mathrm{d}{ }^{-1} \mathrm{~L}^{-1}$ ).
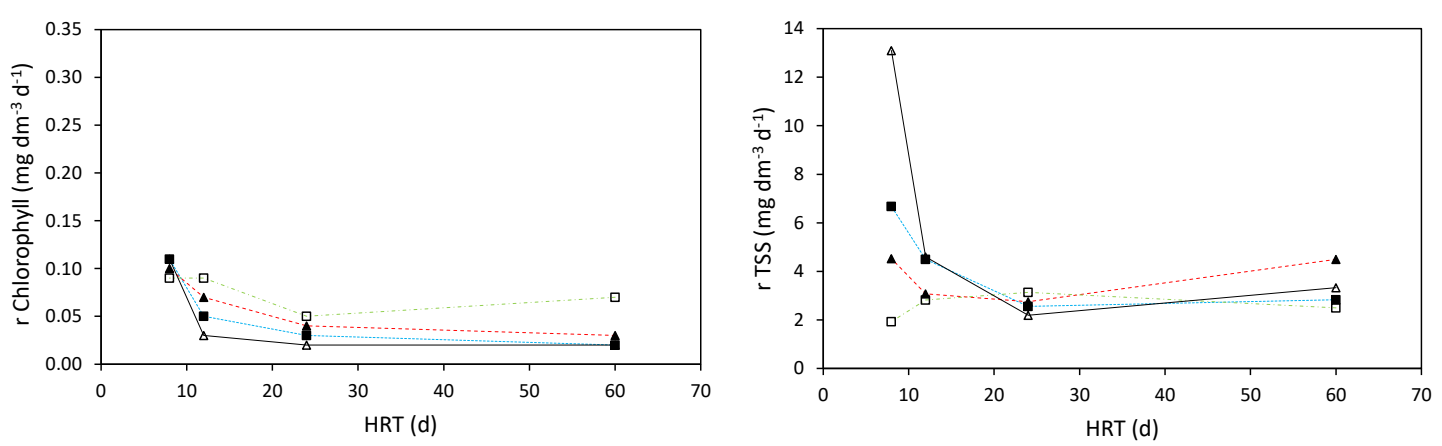

Figure 9. Influence of the HRT on the steady-state production of algae in semicontinuous bioreactors illuminated with $\square$ blue, $\square$ green, $\boldsymbol{\Delta}$ red and $\Delta$ white light and operated at high temperatures ( $\left.\mathrm{T}: 33^{\circ} \mathrm{C}\right) . \mathrm{CLR} 18.33 \mathrm{mg} \mathrm{C} \mathrm{d}^{-1} \mathrm{~L}^{-1}$

Same differences are observed when CLR is evaluated (Figure 10), with values of chlorophyll in the same range than those obtained operating at $19.3{ }^{\circ} \mathrm{C}$ and higher concentration of TSS, explained in terms of the wider range of CLR studied. Fluctuation of results is much higher an even it seems to indicate that there are intermediate CLRs for which production is optimum and that ranges between 40 and $60 \mathrm{mg} \mathrm{C} \mathrm{d}^{-1} \mathrm{~L}^{-1}$, depending on the light illuminated. 

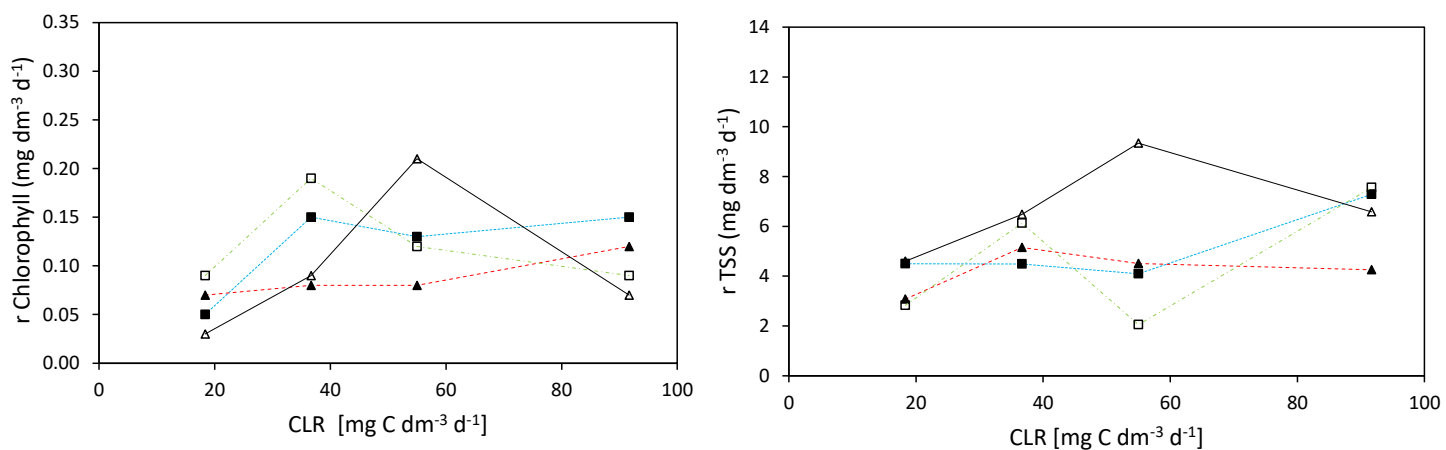

405

Figure 10. Influence on the steady-state solid algae production of the nutrient load fed to

407

408

409

410

411

412

413

414

415

416

417

418

419

420

421

422

423

semi-continuous bioreactors illuminated with $\square$ blue, $\square$ green, $\boldsymbol{\Delta}$ red and $\Delta$ white light, operated at high temperatures $\left(\mathrm{T}: 33^{\circ} \mathrm{C}\right)$. Hydraulic retention time: 12 days.

\subsection{Productivity and quality of biomass as fuel}

Maximum production rates measured within the conditions studies are about $14 \mathrm{mg}$ TSS $\mathrm{L}^{-1} \mathrm{~d}^{-1}$ and they were obtained operating at low HRT. A last important parameter to be discussed is the relationship between total suspended solids and COD, because the final aim of our study is to evaluate the production of algae as feed for biological devices in which electricity is harvested from organic matter (within the research portfolio of our Lab). Figure 11 shows this correlation, where it can be seen that there is a linear trend between both parameters, which is not influenced by the type of light illuminated. Each $\mathrm{mg}$ of TSS produces nearly $3.134 \mathrm{mg}$ of COD and this means that maximum production of substrate according to the results obtained in this work is around $44 \mathrm{mg} \operatorname{COD~d}^{-1} \mathrm{~L}^{-1}$. This value also help to calculate the efficiency of the process in terms of COD produced, which can be calculated from the relationship between this later parameter and the inorganic carbon assimilated and that in the present work ranges between 0.1 and $5.1 \mathrm{mg}$ COD produced $\mathrm{mg}^{-1}$ inorganic carbon fed. 


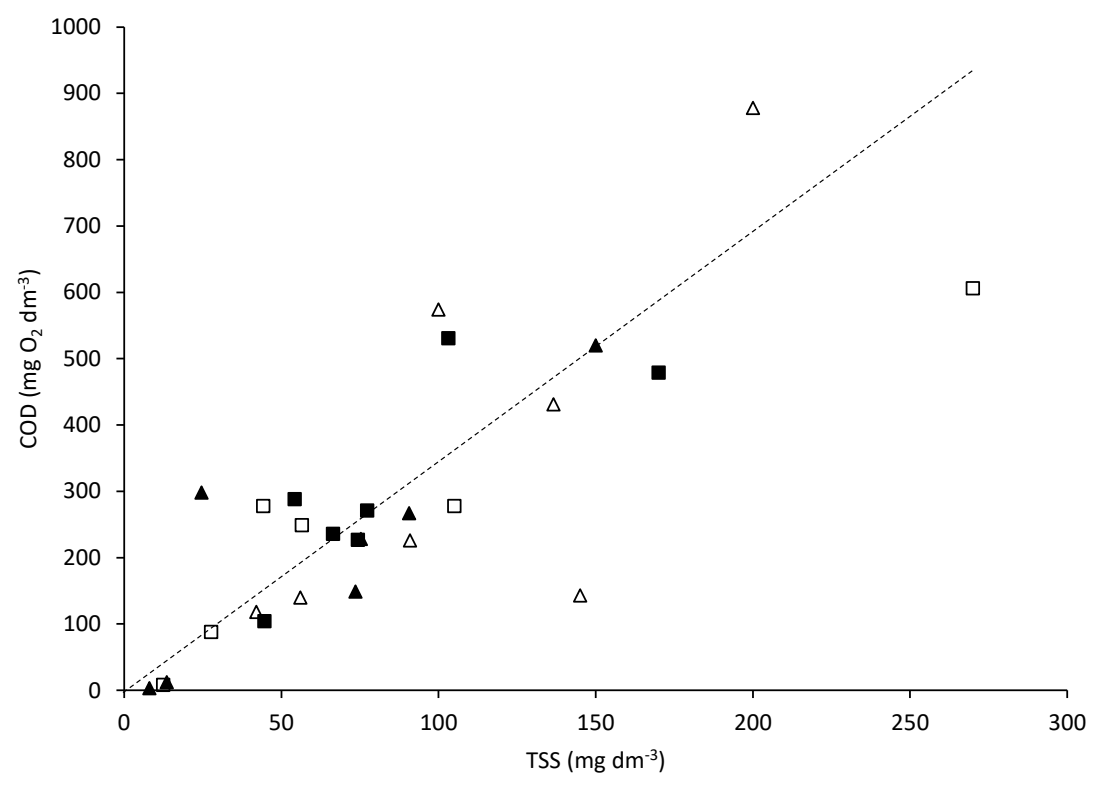

425

426 Figure 11. COD vs. TSS in the algae bioreactors illuminated with $\square$ blue, $\square$ Green, $\boldsymbol{\Delta}$ red 427 and $\triangle$ white light.

428

429 In order to know further about the quality of the product, it is interesting to compare it with a very interesting parameter: the mean oxidation state of carbon (MOSC) in the product stream of the algae bioreactor. This parameter informs about how oxidized is carbon in organic molecules and can be used as a clear indicator of the value of an organic compound as a fuel. MOSC can be calculated according to eq. 2 and it ranges from -4 for methane (the best fuel in terms of oxidation state of carbon) to +4 for carbon dioxide (species with nil fuel capacity).

$$
M O S C=4\left(1-\frac{C O D}{T O C}\right)
$$

437 This equation has been readapted in this work by substituting COD by the production rate of COD and TOC by the carbon fixation rate, in order to apply it to obtain information about the quality of the mixed liquor obtained as a potential fuel. Figure 12 shows the influence of the HRT on this parameter. 

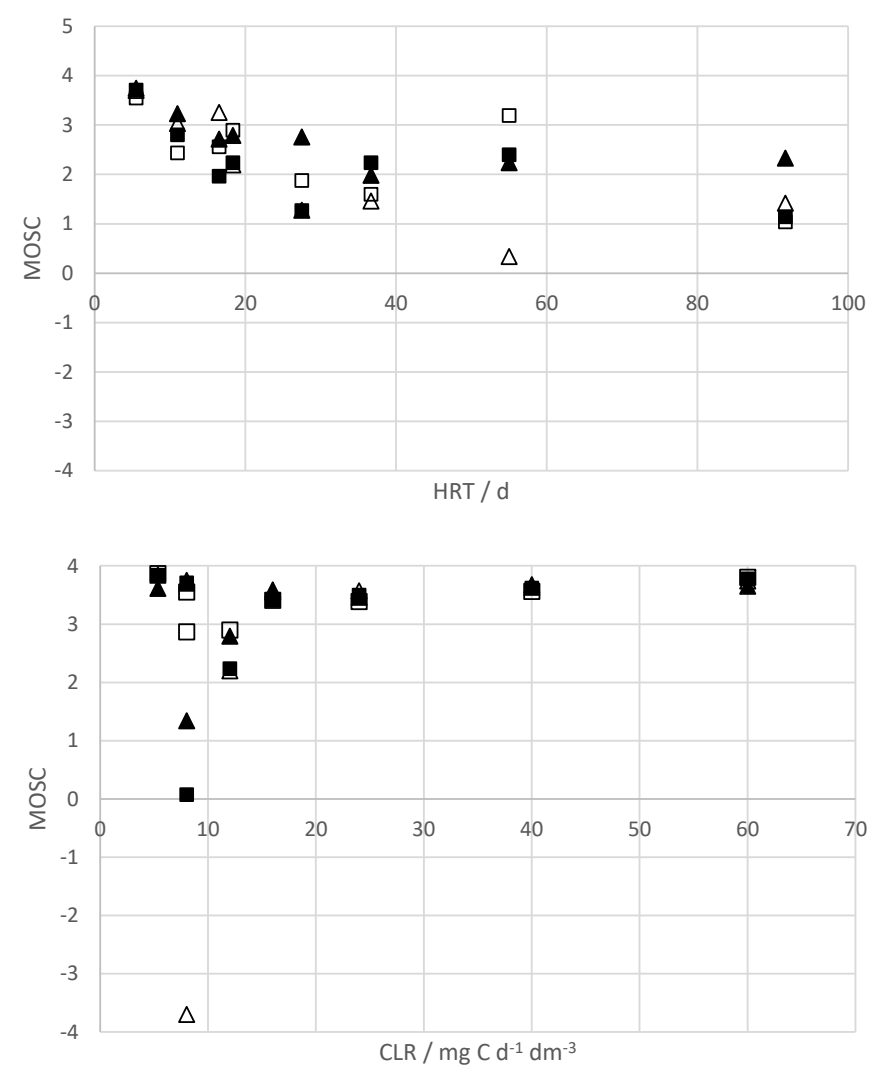

442 Figure 12. Influence of the HRT and CLR on the fuel characteristics (expressed as 443 MOSC) of the product obtained in the bioreactors illuminated with $\square$ blue, $\square$ green, $444 \Delta$ red and $\triangle$ white light.

445 As it can be observed, the higher the HRT (and hence the SRT), the lower is the resulting 446 MOSC, clearly pointing out a higher quality of the product as substrate because carbon 447 assimilated is in a lower average oxidation state and hence it could be expected that 448 performs as a better fuel. Opposite to it could be expected, there is not a clear influence 449 of temperature or light illumination on the quality of the fuel produced and all points 450 followed the same trends marked by the HRT. In comparing the effect of the CLR, a very 451 strange behavior (although reproducible for the four illuminations tested) is observed, 452 with an optimum value around $10 \mathrm{mg} \mathrm{C} \mathrm{d}^{-1} \mathrm{dm}^{-3}$, for which the MOSC decrease suggesting the production of a higher quality fuel. This point is difficult to explain at the 
454 light of the present knowledge and further studies are being carried out in order to 455 understand it.

456 Rates of TSS and chlorophyll calculated by mass balances are not typically evaluated in 457 other papers and hence, it is difficult to compare directly the results. However, when using 458 the same procedures for calculation than those reported in the literature (Sun et al., 2018; 459 Cheng et al., 2016), the biomass and chlorophyll productivity values obtained in this work 460 are quite similar to the results shown by other authors in the literature with axenic cultures 461 fed with bicarbonate or $\mathrm{CO}_{2}$, as it is shown in Table 4.

463 Table 4. Productivities of Chlorella Vulgaris under different cultivation conditions 464

465

466

467 


\begin{tabular}{|c|c|c|c|c|c|c|c|c|}
\hline Authors & $\begin{array}{l}\text { Initial } \\
\text { biomass } \\
\left(\mathrm{mg} \mathrm{L}^{-1}\right)\end{array}$ & $\begin{array}{c}\text { Culture } \\
\text { Axenic/ } \\
\text { Pure }\end{array}$ & Carbon source /Composition & $\begin{array}{l}\text { cultivation condition/operation / } \\
\text { energy source/ light dark ratio }\end{array}$ & $\begin{array}{l}\text { Temperature } \\
\text { oC }\end{array}$ & $\begin{array}{c}\text { biomass } \\
\text { concentration } \\
\left(\mathrm{mg} \mathrm{L}^{-1}\right)\end{array}$ & $\begin{array}{l}\text { growth } \\
\text { rates } \\
\left(\mathrm{mg} \mathrm{L}^{-1} \mathrm{~d}^{-}\right. \\
1)\end{array}$ & $\begin{array}{l}\text { chlorophyll a } \\
\left(\mathrm{mg} \mathrm{L}^{-1}\right)\end{array}$ \\
\hline 1 & 175 & \multirow{3}{*}{ no/no } & $\mathrm{NaHCO}_{3} \mathrm{CLR}=5.5 \mathrm{mg} \mathrm{L}^{-1} \mathrm{~d}^{-1}$ & \multirow{3}{*}{$\begin{array}{c}\text { Phototrophic/ } \\
\text { Semi-continue (SBR) / } \\
\text { green LED (3075 lux)/ } \\
12: 12\end{array}$} & \multirow{2}{*}{19} & 350 & 58 & 6,5 \\
\hline 1 & 150 & & $\mathrm{NaHCO}_{3} \mathrm{CLR}=8 \mathrm{mg} \mathrm{L}^{-1} \mathrm{~d}^{-1}$ & & & 400 & 83 & 4,5 \\
\hline 1 & 50 & & $\mathrm{NaHCO}_{3} \mathrm{CLR}=18.33 \mathrm{mg} \mathrm{L}^{-1} \mathrm{~d}^{-1}$ & & 33 & 115 & 22 & 1,7 \\
\hline 2 & 100 & yes/yes & $\mathrm{CO}_{2} 5 \% 0.15 \mathrm{vvm}$ & $\begin{array}{l}\text { Photoautotrophic/ (SBR)/ LED light } \\
\left(360 \mu \mathrm{mol} \mathrm{m}^{-2} \mathrm{~s}^{-1}\right) 12: 12\end{array}$ & 25 & 3510 & 516 & - \\
\hline 3 & & yes/yes & $\begin{array}{l}\text { Digested Starch } \\
\mathrm{DQO}=936 \mathrm{mg} \mathrm{L}^{-1}\end{array}$ & $\begin{array}{c}\text { Photohetetrophic/ (SBR)/ light } \\
\left(220 \mu \mathrm{mol} \mathrm{m}^{-2} \mathrm{~s}^{-1}\right) / 24: 00\end{array}$ & 35 & 3390 & 520 & - \\
\hline 4 & 400 & yes/yes & $\begin{array}{c}\mathrm{NaHCO}_{3} 275 \mathrm{mg} \mathrm{L}^{-1} \mathrm{~d}^{-1} \\
\text { Glucose DQO } 490 \mathrm{mg} \mathrm{L}^{-1}\end{array}$ & $\begin{array}{l}\text { Photohetetrophic/(SBR)/ Fluorescent } \\
\text { light }\left(100 \mu \mathrm{mol} \mathrm{m}{ }^{-2} \mathrm{~s}^{-1}\right) / 24: 00\end{array}$ & 25 & 2100 & 280 & - \\
\hline \multirow{5}{*}{5} & \multirow{5}{*}{20} & \multirow{5}{*}{ yes/yes } & $\mathrm{NaHCO}_{3} 1 \mathrm{~g} \mathrm{~L}^{-1}$ & \multirow{2}{*}{$\begin{array}{l}\text { Phototrophic/ (PBR)/ fluorescent light } \\
(14 \mathrm{~V}) / 16: 8\end{array}$} & \multirow{5}{*}{25} & 460 & - & - \\
\hline & & & $\mathrm{CO}_{2} 2 \% 0.2 \mathrm{vvm}$ & & & 5000 & -- & - \\
\hline & & & \multirow{2}{*}{ Glucose $10 \mathrm{~g} \mathrm{~L}^{-1}$} & $\begin{array}{l}\text { heterotrophic/ (PBR)/ organic } \\
\text { carbon/16:8 }\end{array}$ & & 250 & - & - \\
\hline & & & & $\begin{array}{l}\text { photoheterotrophic/ (PBR)/ } \\
\text { fluorescent light }(14 \mathrm{~V}) / 16: 8\end{array}$ & & 3800 & - & - \\
\hline & & & $\begin{array}{l}\mathrm{CO}_{2} 2 \% 0.2 \mathrm{vvm} \\
\text { Glucose } 10 \mathrm{~g} \mathrm{~L}^{-1}\end{array}$ & $\begin{array}{l}\text { Mixotrophic/(PBR)/ fluorescent light } \\
\text { (14V) and organic carbon/16:8 }\end{array}$ & & 2100 & - & - \\
\hline \multirow{3}{*}{6} & 220 & \multirow[t]{3}{*}{ yes/yes } & $\begin{array}{c}\mathrm{NaHCO}^{3} 200 \mathrm{mg} \mathrm{L}^{-1} \\
\text { Palm oil mil DQO }=648 \mathrm{mg} \mathrm{L}^{-1}\end{array}$ & $\begin{array}{c}\text { Mixotrophic/Discontinue/ light(3000 } \\
\text { lux }) / 24: 00\end{array}$ & \multirow{3}{*}{$26-28$} & 310 & 8 & - \\
\hline & 250 & & $\begin{array}{c}\text { Glicerol } 600 \mathrm{mg} \mathrm{L}^{-1} \\
\text { Palm oil mill } \mathrm{DQO}=648 \mathrm{mg} \mathrm{L}^{-1}\end{array}$ & \multirow{2}{*}{$\begin{array}{l}\text { Photoheterotrophic/ Discontinue/ } \\
\text { light (3000 lux }) / 24: 00\end{array}$} & & 980 & 100 & - \\
\hline & 250 & & $\begin{array}{c}\text { Glucose } 1 \mathrm{~g} \mathrm{~L}^{-1} \\
\text { Palm oil mill } \mathrm{DQO}=648 \mathrm{mg} \mathrm{L}^{-1}\end{array}$ & & & 1430 & 120 & - \\
\hline 7 & 80 & yes/yes & $\begin{array}{c}\text { Glycerol } 2 \mathrm{~g} \mathrm{~L}^{-1} \\
\mathrm{CO}_{2} 2 \% 0.2 \mathrm{vvm} \\
\end{array}$ & $\begin{array}{l}\text { Phototrophic/(PBR)/ light } \\
\left(75-120 \mu \mathrm{mol} \mathrm{m}^{-2} \mathrm{~s}^{-1}\right) / 24: 00\end{array}$ & 23 & & 36 & 10 \\
\hline \multirow{2}{*}{8} & \multirow{2}{*}{310} & \multirow{2}{*}{ yes/yes } & $\mathrm{CO}_{2} 3 \% 600 \mathrm{ml} \mathrm{min}^{-1}$ & \multirow{2}{*}{$\begin{array}{l}\text { Phototrophic (PBR)/ white } \\
\text { fluorescent }\left(500 \mu \mathrm{mol} \mathrm{m} \mathrm{m}^{-2} \mathrm{~s}^{-1}\right) / 24: 00\end{array}$} & 25 & 2150 & 538 & 10,8 \\
\hline & & & $\mathrm{CO}_{2} 3 \% 600 \mathrm{ml} \mathrm{min}^{-1}$ & & 25 & - & 1013 & 4,4 \\
\hline
\end{tabular}

${ }^{1}$ This study, ${ }^{2}$ Sun et al., 2018, ${ }^{3}$ Cheng et al., 2016, ${ }^{4}$ Mujtaba et al., 2018, ${ }^{5}$ Yeh et al., 2012, ${ }^{6}$ Azimatun and Hadiyanto, 2015, ${ }^{7}$ Ge et al., $2018,{ }^{8}$ Cho et al., 2016 


\section{Conclusions}

471

472 According to the results obtained in this work, microalgae can be effectively produced in 473 bath operated bioreactors illuminated with LEDs. The green light is the lighting that most 474 benefits the development of Chlorella vulgaris culture. Three parameters (HRT, CLR and 475 color) have demonstrated a great influence on the production and quality of the mixed 476 liquor obtained in the bioreactors. As a general trend, HRT shows a positive effect on the 477 production of algae. However, despite this observation, maximum production at high 478 operating temperature is obtained at the lowest HRT, indicating that at least two 479 controlling mechanisms are involved in the production process. Likewise, it was verified that within the range $0-60 \mathrm{mg} \mathrm{C} \mathrm{L}^{-1} \mathrm{~d}^{-1}$, CLR also influences positively on the production of algae. Maximum production rates observed are around $44 \mathrm{mg} \mathrm{COD} \mathrm{L} \mathrm{C}^{-1} \mathrm{~d}^{-1}$, which are within the limits obtained by other authors.

483 Finally, regarding the quality of the mixed liquor produced, the higher the HRT, the lower 484 is the resulting MOSC, indicating the production of a potentially better fuel. Concerning the CLR, an optimum value is clearly observed around $10 \mathrm{mg} \mathrm{C} \mathrm{L}^{-1} \mathrm{~d}^{-1}$ regardless of the light color illuminated.

\section{Acknowledgements}

489 Financial support from Spanish Ministry of Economy and Competitiveness (MINECO) through project CTQ2013-49748-EXP (Explora Program) is gratefully acknowledged

\section{References}


Ahmad, J., Bazaka, K., Anderson, L.J., White, R.D., Jacob, M.V., 2013. Materials and methods for encapsulation of OPV: A review. Renew. Sustainable Energy Rev., 27, 104117.

Amin, S., 2009. Review on biofuel oil and gas production processes from microalgae. Energ. Convers. Manage., 50, 1834-1840.

Asensio, Y., Fernandez-Marchante, C.M., Lobato, J., Cañizares, P., Rodrigo, M.A. 2016 Influence of the fuel and dosage on the performance of double-compartment microbial fuel cells. Water Research 99, 16-23

Asensio, Y., Fernandez-Marchante, C.M., Villaseñor, J., Lobato, J., Cañizares, P., Rodrigo, M.A., 2018. Algal biomass as fuel for stacked-MfCs for profitable, sustainable and carbon neutral bioenergy generation. Journal of Chemical Technology and Biotechnology 93, 1, 287-293

Aslan, S., Kapdan, I.K., 2006. Batch kinetics of nitrogen and phosphorus removal from synthetic wastewater by algae. Ecol. Eng., 28, 64-70.

Azimatun, M.M., Hadiyanto, H, 2015. Enhancement of Chlorella vulgaris biomass cultivated in POME medium as biofuel feedstock ander mixotrophic conditions. J.Eng. Tehnol. Sci, 47, 487-497.

Bialon, J., Rath, T. 2018 Growth rates and photon efficiency of Chlorella vulgaris in relation to photon absorption rates under different LED-types. Algal Research 31, 204215.

Caporgno, M.P., Taleb, A., Olkiewicz, M., Font, J., Pruvost, J., Legrand, J., Bengoa, C., 2015. Microalgae cultivation in urban wastewater: Nutrient removal and biomass production for biodiesel and methane. Algal Res., 10, 232-239.

Cheng, B., Ge, Z., Zhao, Y., Sun, S., Hu, C., 2016. Nutrient removal and biogas upgrading by microalgal strains cultured in anaerobic digested starch wastwater. .J. Chem Technol Biotechnol, 91, 3028-3034.

Chen, W.-H., Lin, B.-J., Huang, M.-Y., Chang, J.-S., 2015. Thermochemical conversion of microalgal biomass into biofuels: A review. Bioresour. Technol., 184, 314-327.

Cho, D., Ramanan, R., Heo, J., S., D., Oh, H., Kim, H., 2016. Influence of limiting factors on biomass and lipid productivities of axenic Chlorella vulgaris in photobioreactor under chemostat cultivation, 211, 367-373.

Farooq, W., Moon, M., Ryu, B.-g., Suh, W.I., Shrivastav, A., Park, M.S., Mishra, S.K., Yang, J.-W., 2015. Effect of harvesting methods on the reusability of water for cultivation of Chlorella vulgaris, its lipid productivity and biodiesel quality. Algal Res., 8 1-7.

Fernández-Marchante, C.M., Asensio, Y., León, L.F., Cañizares, P., Lobato, J., Rodrigo, M.A. 2018. Thermally-treated algal suspensions as fuel for microbial fuel cells. Journal of Electroanalytical Chemistry 814, 77-82.

Filali, R., Badea, A.C., Tebbani, S., Dumur, D., Diop S., Pareau, D., Lopes, F., 2011. Optimization of the Interval Approach for Chlorella vulgaris Biomass Estimation, 50th Ieee Conference on Decision and Control and European Control Conference (Cdc-Ecc), 4554-4559. 
Ge, S., Qiu, S., Tremblay, D., Viner, K., Champagne, P., Jessop, P., 2018. Centrate wastewater treatment with Chlorella vulgaris: Simultaneous enhancement of nutrienet removal, biomass and lipid production. Chemicla Engineering Journal 342, 310-320.

Gonzalez del Campo, A., Cañizares, P., Rodrigo, M.A., Fernandez, F.J., Lobato, J., 2013. Microbial fuel cell with an algae-assisted cathode: A preliminary assessment. J. Power Sources, 242, 638-645.

Guieysse, B., Bechet, Q., Shilton, A., 2013. Variability and uncertainty in water demand and water footprint assessments of fresh algae cultivation based on case studies from five climatic regions. Bioresour. Technol., 128 317-323.

Gutierrez-Wing, M.T., Silaban, A., Barnett, J., Rusch, K.A., 2014. Light irradiance and spectral distribution effects on microalgal bioreactors. Eng. Life Sci., 14, 574-580.

He, L., Subrarnanian, V.R., Tang, Y.J., 2012. Experimental analysis and model-based optimization of microalgae growth in photo-bioreactors using flue gas. Biomass Bioenerg., 41, 131-138.

Jacob-Lopes, E., Cacia Ferreira Lacerda, L.M., Franco T.T., 2008. Biomass production and carbon dioxide fixation by Aphanothece microscopica Nageli in a bubble column photobioreactor. Biochem. Eng. J., 40, 27-34.

Jacob-Lopes, E., Gimenes Scoparo, C.H., Cacia Ferreira Lacerda, L.M., Franco, T.T., 2009. Effect of light cycles (night/day) on $\mathrm{CO} 2$ fixation and biomass production by microalgae in photobioreactors. Chem. Eng. Process., 48, 306-310.

Lobato, J., Gonzalez del Campo, A., Fernandez, F.J., Cañizares, P., Rodrigo M.A., 2013. Lagooning microbial fuel cells: A first approach by coupling electricity-producing microorganisms and algae. Appl. Energ., 110, 220-226.

Martinez, M.E., Jimenez, J.M., El Yousfi, F., 1999. Influence of phosphorus concentration and temperature on growth and phosphorus uptake by the microalga Scenedesmus obliquus. Bioresour. Technol., 67 233-240.

Mohsenpour, S.F., Willoughby, N., 2013. Luminescent photobioreactor design for improved algal growth and photosynthetic pigment production through spectral conversion of light. Bioresour. Technol., 142, 147-153.

Mujtaba, G., Rizwan, M., Kim, G., Lee, K. 2018. Removal of nutrients and COD through co-culturing activated sludge and immobilized Chlorella vulgaris. Chemical Engineering Journal 343, 155-162.

Murphy, C.F., Allen, D.T., 2011. Energy-Water Nexus for Mass Cultivation of Algae. Environ. Sci. Technol., 45, 5861-5868.

Park, J., Seo, J., Kwon, E.E., 2012. Microalgae Production Using Wastewater: Effect of Light-Emitting Diode Wavelength on Microalgal Growth. Environ. Eng. Sci., 29, 9951001.

Park, J.B.K., Craggs, R.J., Shilton, A.N., 2011. Recycling algae to improve species control and harvest efficiency from a high rate algal pond. Water Res., 45 6637-6649. Patzelt, D.J., Hindersin, S., Elsayed, S., Boukis, N., Kerner, M., Hanelt, D., 2015. Microalgal growth and fatty acid productivity on recovered nutrients from hydrothermal gasification of Acutodesmus obliquus. Algal Res., 10, 164-171. 
577 Penteado, E.D., Fernandez-Marchante, C.M., Zaiat, M., Cañizares, P., Gonzalez, E.R.,

578 Rodrigo, M.A. Influence of sludge age on the performance of MFC treating winery 579 wastewater 2016 Chemosphere 151, 163-170

580 Ruiz, J., Alvarez-Diaz, P.D., Arbib, Z., Garrido-Perez, C., Barragan, J., Perales, J.A., 581 2013. Performance of a flat panel reactor in the continuous culture of microalgae in urban 582 wastewater: Prediction from a batch experiment. Bioresour. Technol., 127 456-463.

583 Ruiz-Marin, A., Mendoza-Espinosa, L.G., Stephenson, T., 2010. Growth and nutrient 584 removal in free and immobilized green algae in batch and semi-continuous cultures treating real wastewater. Bioresour. Technol., 101 58-64.

Rusten, B., Sahu, A.K., 2011. Microalgae growth for nutrient recovery from sludge liquor and production of renewable bioenergy. Water Sci Technol., 64, 1195-1201. Sasi, D., Mitra, P., Vigueras, A., Hill, G.A.,2011. Growth kinetics and lipid production using Chlorella vulgaris in a circulating loop photobioreactor. J. Chem. Technol. Biot., 86, 875-880.

591 Schulze, P.S.C., Barreira, L.A.,. Pereira, H.G.C, Perales, J.A., Varela, J.C.S., 2014. Light emitting diodes (LEDs) applied to microalgal production. Trends Biotechnol., 32, 423431.

Senez, J.C., 1962. Some considerations on energetics of bacterial growth. Bacteriol. Rev., 26, 95-107.

596 Sostaric, M., Golob, J., Bricelj, M., Klinar, D., Pivec, A., 2009. Studies on the Growth of 597 Chlorella vulgaris in Culture Media with Different Carbon Sources. Chem. Biochem. 598 Eng. Q., 23, 471-477.

599 Souza, F.L., Cotillas, S., Saéz, C., Cañizares, P., Lanza, M.R., Seco, A., Rodrigo, M.A., 600 2016. Removal of algae from biological cultures: A challenge for electrocoagulation?. J. 601 Chem. Technol. Biot., 91, 82-87.

602 Sun, Y., Liao, Q., Huandg, Y., Xia, A., Fu, A., Zhu, X., Fu, J., Li, J. 2018. Application of 603 growth-phase based light-feeding strategies to simultaneously enhance Chlorella vulgaris 604 growth and lipid accumulation. Bioresource Technology 256, 421-430.

605 Terashima, I., Fujita, T., Inoue, T., Chow, W.S., Oguchi, R., 2009. Green Light Drives 606 Leaf Photosynthesis More Efficiently than Red Light in Strong White Light: Revisiting 607 the Enigmatic Question of Why Leaves are Green. Plant Cell Physiol., 50, 684-697.

608 Villaseñor, J., Rodríguez, L., Fernández-Marchante, C.M., Fernández, F.J., Rodrigo, 609 M.A. 2017. The salinity effects on the performance of a constructed wetland-microbial 610 fuel cell Ecological Engineering 107, 1-7.

611 Xin, L., Hu, H.-y., Ke, G., Sun, Y.-x., 2010. Effects of different nitrogen and phosphorus 612 concentrations on the growth, nutrient uptake, and lipid accumulation of a freshwater 613 microalga Scenedesmus sp. Bioresour. Technol., 101, 5494-5500.

614 Yeh, K.-L., Chang, J.-S., Chen, W.-m., 2010. Effect of light supply and carbon source on 615 cell growth and cellular composition of a newly isolated microalga Chlorella vulgaris 616 ESP-31. Eng. Life Sci., 10, 201-208.

617 Yeh, K.-L., Chang, J.-S., 2012. Effects of cultivations conditions and media composition 618 on cell growth and lipid productivity of indigenous microalga Chlorella vulgaris ESP-31. 619 Bioresource Technology 105, 120-127. 
621 CO2 fixation to biofuel production. Renew. Sustainable Energy Rev., 15, 3252-3260.

622

623 